\title{
The most unlikely places
}

\author{
LARRY SIMPSON \\ Microbiology, Immunology and Molecular Genetics, Geffen School of Medicine at UCLA, Los Angeles, California 90095-1489, USA
}

For me humor has always been the saving grace of the human condition and I always look for humor in the most unlikely places. I will never forget telling Joan Steitz and several others at a meeting when they were planning to have an RNA Society and Journal, "How can you have a Society based on a 2' hydroxyl?" Well fortunately they did not take my advice and so was born the RNA journal. Its birth throes coincided (probably intentionally) with an explosion of knowledge about RNA. (Full disclosure-this memory was sent out for historical peer review and did not fare so well, but it does lie there in the corners of my aging brain.)

My first love affair however was not with RNA but with the cultured trypanosomatid flagellated parasites, Leishmania. I loved just looking at them swim around in the phase contrast microscope. And when the cells were smeared onto a slide and stained with Giemsa you could see a prominent dark blue structure at the base of the flagellum known as the kinetoplast. Maurice Steinert had shown that this was a mitochondrion that contained a large mass of DNA and, on the suggestion of William Trager, my graduate advisor, I decided to find out what it was. I thought with my usual arrogance that it would take me around two to three years and then I would look for a real thesis problem. But I arrived at UCLA in 1968 still studying the same phenomenon. Fortunately my first graduate student, Agda da Silva, took an EM lab course from Fred Eisserling and she discovered that the the kinetoplast DNA was composed of thousands of small circular DNA molecules all catenated together to form a giant DNA network. Then came the realization from the work of the Piet Borst lab that there was a second minor catenated DNA species which he called the maxicircle. We showed that the maxicircle contained mitochondrial rRNA and protein genes and the minicircles turned out to be heterogeneous in sequence and did not contain any open reading frame. This provided yet another perplexing problem which we did not solve for a few years.

Well, more than 40 years later I am still studying the kinetoplast and its DNA. I did however branch out to its mitochondrial RNA, mainly because of a paper by Rob Benne with the bizzare suggestion that the mitochondrial mRNA

Corresponding author: larrys3255@gmail.com

Article and publication date are at http://www.rnajournal.org/cgi/doi/ $10.1261 /$ rna.050088.115. Freely available online through the RNA Open Access option. of a related trypanosomatid differed in sequence from the DNA in having four extra uridines inserted at three sites which overcame a - 1 frameshift. In those days, I didn't really believe anything until I did it myself, and when my graduate student, Janet Shaw, came into my office with a fresh autoradiograph showing that indeed kinetoplast maxicircle mRNAs in Leishmania also had extra uridines at specific sites, there were a lot more than just four nucleotides. And then another student, Nancy Sturm, came in and showed me a gel showing that there were also $U$ deletions as well as $U$ insertions. And then came the incredible cover of Cell from the Stuart lab that showed a pan-edited gene almost created de novo by editing. Those were heady days with this kind of mystifying data and the really perplexing question of where was the information for the insertion and deletion of U's. Then in $1990 \mathrm{my}$ Swiss postdoc, Beat Blum helped us figure this all out-the information was in the form of small RNAs that were complementary to the edited mRNA sequences and guided the insertion-deletion of U's to specific sites. The information for specificity lay in simple base pairing and we coined the term, guide RNAs or gRNAs, to describe these RNAs. Some gRNAs were encoded in the maxicircle but Nancy Sturm discovered that they were mostly encoded in the minicircles, which finally provided an explanation for these enigmatic molecules. Having these gRNAs led us directly to propose a model for the mechanism that has turned out to be mostly correct but much more complex than we originally thought. A great deal of progress has been made in the trypanosome editing field since then by several labs. But I won't describe this since I want to discuss the development of other types of RNA editing in the last 20 years, from both scientific and "socio-politico" points of view.

In his seminal paper, Benne had coined the term, RNA editing, and this term became the flavor of the week for a while to describe a variety of post- and co-transcriptional RNA modifications, most of which appeared unrelated either in a mechanistic and/or evolutionary sense. In fact the main way that these diverse phenomena were related was in the form of a Gordon Conference on RNA Editing which encompassed all types of editing.

(c) 2015 Simpson This article, published in RNA, is available under a Creative Commons License (Attribution-NonCommercial 4.0 International), as described at http://creativecommons.org/licenses/by-nc/4.0/. 
Other systems were rapidly discovered such as a single C to $U$ deamination in the apoB mRNA in mammals which created a stop codon and produced a truncated apoB protein that the Davidson lab showed had physiological consequences. The site specificity mechanism did not use trans acting factors but was shown by the Smith lab to utilize a short protein-binding "mooring sequence" in the $3^{\prime}$ region. Superficially similar multiple $\mathrm{C}$ to $\mathrm{U}$ changes were found to occur in higher plant mitochondria and chloroplasts, but these were later found by Shikanai and his colleagues to be mediated by the diverse PPR RNA binding protein family. Interestingly these same proteins were recently shown by the Aphasizhev lab to also be involved in trypanosome RNA editing. Single nucleotide substitutions were also found to occur in tRNAs and rRNAs by the Grey lab and others. And the most challenging editing system of them all was discovered in Physarum mitochondria where multiple types of nucleotide changes occur in what appears from work in the Gott lab to be co-transcriptional.

Some tension developed when the classical rRNA and tRNA nucleotide modification community realized that this was also a type of RNA editing, but the tension was defused by inviting them to participate in the Editing Gordon Conference and by changing the title to RNA Editing and RNA Modification. The site specificity is determined mainly by protein binding, but a subset of rRNA nucleotide modifications were discovered by the Fornier lab and others to be mediated by base-pairing of trans-acting Sno RNAs in most eukaryotes and also in archaea.

Another type of deamination editing which occurred in higher organisms and was really extensive and physiologically significant were the A to I modifications which, due to base pairing of I with C, appeared as A to $\mathrm{G}$ changes. This was investigated by the Bass lab and others and proved to be very important in modifying the physiology of membrane channels and, as shown by the Seeburg and Emeson labs, was regulated in different tissues. In fact this type of editing has essentially taken over the "flavor of the week" aura of trypanosome editing and most people these days immediately associate the term, RNA Editing, with this phenomenon.

Finally, the discovery of RNA interference by Andy Fire and Craig Mello was probably the most significant event in the last 20 years in the RNA modification field. The phenomenon was that double strand RNA from a specific mRNA could induce selective degradation of that mRNA. The site specificity involved trans-acting guide RNAs, known as Si RNAs, that base-paired with the target mRNA and recruited the slicer nuclease which cut the mRNA at the precise sites determined by base-pairing with the Si RNA. This turned out to be involved in eukaryotic development as well as in protection from RNA viruses and transposable elements. RNA interference also became an important genetic engineering tool.

The search for Si RNAs led rapidly to the discovery by the Bartel Lab and others of microRNAs which regulated translation by forming imperfect base paring with the $3^{\prime}$ region of the mRNAs. This led to the realization of how important and widespread is RNA regulation of genetic activity and how much of the genome is involved with the regulation of genetic pathways by microRNAs. I feel that this realization that RNA and not protein is the major player in genetic regulation was a major paradigm shift and I rank this conceptual framework change as the most significant RNA discovery in the years since the RNA journal was founded.

I end this historical scientific mini-essay with the realization that I was definitely wrong and that the creation of a scientific society and journal based on a $2^{\prime}$ hydroxyl group was definitely feasible and worthwhile. Congratulations to the $R N A$ journal and may it have another 20 fruitful years! 

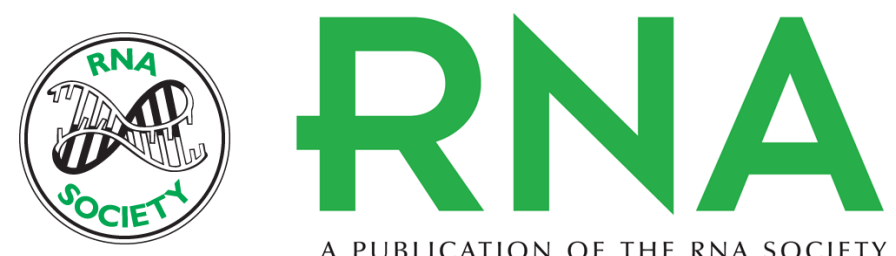

A PUBLICATION OF THE RNA SOCIETY

\section{The most unlikely places}

Larry Simpson

RNA 2015 21: 740-741

Open Access Freely available online through the RNA Open Access option.

Creative This article, published in $R N A$, is available under a Creative Commons License

Commons (Attribution-NonCommercial 4.0 International), as described at

License http://creativecommons.org/licenses/by-nc/4.0/.

Email Alerting Receive free email alerts when new articles cite this article - sign up in the box at the Service top right corner of the article or click here.

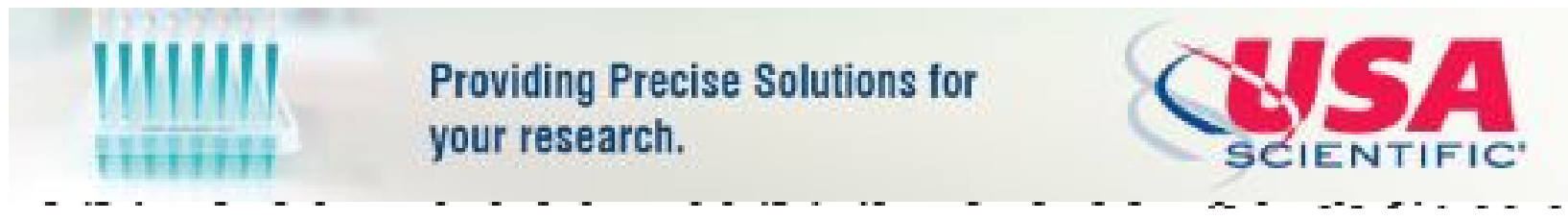

To subscribe to $R N A$ go to:

http://rnajournal.cshlp.org/subscriptions

(C) 2015 Simpson; Published by Cold Spring Harbor Laboratory Press for the RNA Society 